\title{
The Risk of Information Technology on Employment
}

\author{
Xiaowei Huang \\ Zhuhai Campus, Beijing Institute of Technology \\ E-mail: janey710@yahoo.com
}

\begin{abstract}
The investigation of whether or not the development of technology has become the enemy of employment is a boundless topic. There is no denying that technology plays an indispensable role in today's society. However, the changing status of employment shows that with the development of technologies, the requirements of employees are not longer merely based on the basic skills and traditional knowledge, which was required before. In fact, under the development of information technology, employees seem have to undergone more negative effects than positive effects. This paper aims to analyse the relationship between technology and employment, and in particular, the development of information technology.
\end{abstract}

Keywords: Information technology, Technological determinism, Employment

'The opinion, entertained by the labouring class, that the employment of machinery is frequently detrimental to their interests, is not founded on prejudice and error, but is conformable to the correct principles of political economy' (Ricardo, cited in Freeman and Soete 1994: 20).

'This is not technological determinism. Technologies are developed and diffused by human individuals and institutions; the processes of development, selection, shaping and application are social processes' (Freeman and Soete 1994: 52).

\section{Introduction}

The investigation of whether or not the development of technology has become the enemy of employment is a boundless topic. Especially in the case of the evolution of computer technology and information technology, according to Brooks, 'technology may not solve all of our problems, but our problems cannot possibly be solved without the information of new technology' (Stephen G. Phitchinis 1983: 4). There is no denying that technology plays an indispensable role in today's society. It is an inevitable consequence of social development. However, the changing status of employment shows that with the development of technologies, the requirements of employees are not longer merely based on the basic skills and traditional knowledge, which was required before. Rather, it seems to employees that more and more professional capability is necessary in order to overcome the feeling of insecurity, and survive in an information society.

This paper aims to analyse the relationship between technology and employment, and in particular, the development of information technology. In general, this is a wide topic, especially in the area of information technology. Therefore, this paper will only focus on analysing the advantages and disadvantages of information technology with its effects on employment.

It will be divided into three major parts. First of all, it will introduce the term "information technology" by analysing its characteristics and potential. Meanwhile, the theme of knowledge and its relationship with information technology will be introduced. Secondly, the conflict between information technology and employment will be investigated. Following the interpretation of evolution from the case of employment, the term "industrialism" will be analysed in the third part of this paper. A conclusion will be provided in the last section of the paper.

\section{Information Technology and Knowledge}

Information technology plays a crucial role in today's society. The term "information society" is simply defined from there. According to Bennett et al.,

'Characteristically, conceptions of an information society embrace evolutionary themes, the term suggesting a higher stage of development than hitherto. In this way the information society retains something of the suggestion of a 
higher-order state evident in the implication of an informed place. This is especially the case when the synonym "knowledge society" is adopted' (2005: 188).

How to survive in an information society? In the case of China, there was a crucial change in the 1980s as the reformation of society was taking place and the institution of liberalism was set up. Under this social evolution, Chinese people could achieve a better life by hard work. Knowledge was not a major aspect for fulfilling an improved life. However, this situation was changed entirely by the new construction of economy and the invasion of information technology. In other words, 'labour is no longer a commodity' (Tapscott 1996: 47). Obviously, knowledge has become a compulsive element for survival under an information society.

Alan Webber questions the fact that 'no one has asked the all important question ... what's so new about the new economy?' (cited in Tapscott 1996: 43). From Tapscott's point of view 'the new economy is a knowledge economy' (Tapscott 1996: 44). In other words, knowledge has become the only one way to achieve better life and wealth.

Drucker divides human employment into two major categories: knowledge workers and service workers. The former category is based on the 'intellectual, cultural, and business elite'; the latter category is based on the workers who are excluded from the former one (Robins 1997: 53). In addition, he explains the fundamental difference between knowledge worker and service workers. As he puts it,

'Knowledge workers are the real generations of wealth. The income of these owners of intellectual and financial wealth will increase substantially, and they will be made welcome anywhere in the world' (Robins 1997: 54).

'Service workers will now be expected to add far more value to the company, unlike in the past where service work meant just turning up. Companies will be reducing the wages and staffing levels of services workers, and it is no accident that most Western companies are presently instigating major downsizing programmes' (Robins 1997: 54).

In the relationship between information technology and knowledge, Tapscott continues, 'information technology enables an economy based on knowledge. But notwithstanding the rise of artificial intelligence and other "knowledge technologies"'(1996: 44). It seems to Drucher that 'knowledge is not simply another resource along with the traditional factors of production such as labor, capital, and land; it is the only meaningful resource today. Consequently, the knowledge worker is any organization's greatest single asset' (1996: 47).

Generally speaking, both labour and knowledge play an important role in the process of social development. However, the argument of who plays a role of determent may depend on a different situation and generation. Phichinis has an opposite point of view with Tapscott, as he stresses that 'labour is the critical factor. Aside from its functional role in relation to land-related production processes, labour is the only factor that transmits knowledge and thereby perpetuates improvements in production processes' (1983: 23). This theory simply coincides with the situation in the 1980s in China. However, a new social structure is formed by knowledge and information. As Castells considers, 'knowledge and information seem indeed to be major sources of productivity and growth in advanced societies' (1996: 204). Actually, Castells' conception is not merely applicable in advanced societies, but is also suitable for every country. As he puts it,

'What is most distinctive, in historical terms, between the economic structures of the first half and of the second half of the twentieth century is the revolution in information technologies, and its diffusion in all spheres of social and economic activity, including its contribution in providing the infrastructure for the formation of a global economy' (1996: 204).

Today, the rapid development of information technology has spread to each corner of the world. Its effects have expanded to all trades and professions. For example, factories, offices, service organisations, etc. Castells points out that 'the role of direct work has increased because information technology has empowered the direct worker at the shop floor level (be it the process of testing chips or underwriting insurance policies). Moreover, Castells explains that 'information technology becomes the critical ingredient of the process of work' as described because:

- It largely determines innovation capability;

- It makes possible the correction of errors and generation of feedback effects at the level of execution;

- It provides the infrastructure for flexibility and adaptability throughout the management of the production process (1996: 243).

\section{Technology and Employment}

'Technology destroys work skills and creates work skills, reduces employment and creates employment' (Phitchinis 1983: 2). Every coin has its two sides. There is no denying that technology has been creating many opportunities in the category of employment, even though it would be arguable that technology may somehow cause unemployment. However, the reasons of unemployment are various: for instance, old work skills have been replaced by new ones; this is not destruction but a circulation of work. Generally speaking, nobody prefers using a work system, which is not 
efficient. Simply as the development of information technology, people prefer using email to contact each other, rather than postal mail. This is because of the speed of delivery and personal preference. Phitchinis explains the major reason that causes decreasing employment. As he points out,

'When some of the work functions of an occupation are removed from it, either because they are no longer needed in the production process, or because they are performed with equal efficiency and at lower cost by some other occupation, or because they have been embodied into mechanical or microelectronic instruments and processes, employment in the occupation will decrease' (1983: 91).

His explanation clearly shows that in a circulation of work, it is reasonable to reduce certain positions or occupations. This is simply because these positions and occupations can be replaced by a machine. Giddens defines a machine as 'an artifact that accomplishes set tasks by employing such power sources as the means of its operation' (1990: 56). If a machine can do exactly what a human can do, it can even do better than a worker. From the employer's position, for instance, to buy a mechanical instrument is one time of investment. Compared with employing a worker, who offers the same labour as a mechanical instrument, the cost of the worker will be higher. The status of a machine would be more stable than a worker; it works according to the way it is operated, until it expends its energy. However, a worker is not guaranteed to work in the same company or factory forever. A worker may change employment any time, or not be able to work suddenly due to illness, for example. Just as Freeman and Soete comment, 'if a machine or computer can do a job more efficiently and cheaply than an employee, it is inevitable that it will be used' (1994: 4).

Furthermore, Castells stresses that 'every other activity, given the extraordinary rate of progress in information technology and its constant lowering in price per information unit, is potentially susceptible of automation, and thus the labor engaged in it is expendable' (1996: 242). In the prediction of jobs reductions, according to Tapscott, 'sales, real estate, life insurance, travel; wholesales, such as food, dry goods and clothing; primary and high school teachers; distributors, for example, postal workers and retail trade' seem are the most risky occupations that are being reduced (1996: 290).

The prediction here is not an unfounded story, as Tapscott lists down the number of jobs in decline according to the information from the Bureau of Labor Statistics: '..between 1992 and 2005 a number of job types will decline by a significant percentage: computer operators (39\%); billing, posting, and calculating machines operators (29\%); telephone operators (28\%); typists and word processing operators (16\%); and bank tellers (4\%)' (1996: 290).

The numbers of jobs in decline show that most jobs here are low-skilled service jobs. In other words, these jobs do not require higher skills or any professional knowledge. Shaiken defines skill as 'a creative response to uncertainty based on experience, ability, and the needs of the situation' (1984: Preface xii). Under the new structure of society and economic institutions, unemployment, or replacements by mechanical instrument will certainly happen sooner or later. The theme of knowledge will be involved once again in the category of employment. The conception of knowledge can be understood through the changing fulfillment of workers. 'In the old economy, workers tried to achieve fulfillment through leisure. In the new economy, fulfillment can be achieved through work and the means of production shifts to the brain of the producers' (Tapscott 1996: 48).

It may be slightly general to prove that knowledge is the one major aspect of survival, or to assure the safety of occupation. However, this interpretation is developed according to the evolution of society and economy. In the case of information technology, Tapscott claims that 'the knowledge content of products and services is growing significantly as consumer ideas and information and technology become part of products. On the other hand, Tapscott explains the relationship between technologies change and unemployment. As he explains,

'In the past, job loss has always been more than compensated for by a parallel process of job creation in new industries, firms, and occupations. Technological change has led to higher real incomes and greater employment. But just as companies that don't embrace the technology will become uncompetitive, any nation that dallies will also face competitive decline - facing the specter of massive structural unemployment' (1996: 290).

Shaiken argues that 'the technical potential is there for new systems to be designed in a way that both enriches life on the job and benefits society. But the potential to make work more creative and satisfying can be very far apart from the reality of the workplace' (1984: Preface xi).

In the case of information computer technology (ICT), Shaiken questions that 'when computerizations is counterposed to human skill, the issue is not simply a "better" method of production but often a choice that reflects certain values and purpose' (1984: Preface xi). The theme of certain values and purpose can be understood as the reducing of price and cause of jobs decline. On the other hand, Freeman and Soete provide five advantages of using ICT:

1. Speed and accuracy of processing and transmitting information;

2. Storage capacity for large quantities of information;

3. Flexibility in organizing manufacturing, design, marketing and organisations; 
4. Networking within and between firms and other individuals and organisations;

5. Display of information (1994: 47).

\section{Industrialism and Informationalism}

According to Castells, the terms' industrialism' and 'informationalism'

'use as the strongest empirical evidence for the change in historical course the coming into being of a new social structure, characterized by the shift from goods to services, by the rise of managerial and professional occupations, by the demise of agricultural and manufacturing jobs, and by the growing information content of work in the most advanced economics' (1996: 202).

In addition, Castells points out the three aspects on the theme of postindustrialism. First of all, he proposes 'to shift the analytical emphasis for postindustrialism (a relevant question of social forecasting still without an answer at the moment of its formulation) to informationalism'. Secondly, 'the criterion of postindustrialist theory by which to consider a society as postindustrial concerns the shift to service activities and the demise of manufacturing'. Finally, 'the third major prediction of the original theory of postindustrialism refers to the expansion of information-rich occupations, such as managerial, professional, and technical positions, as the core of the new occupational structure' (1996: 204-206).

It seems to Giddens that the characteristic of industrialism is 'the use of inanimate sources of material power in the production of goods, coupled to the central role of machinery in the production process' (1990: 55-56). Moreover, he continues explaining that 'the notion of industrialism is applied to high-technology settings where electricity is the only power source, and where electronic microcircuits are the only mechanized devices' (1990: 56). In other words, no matter how powerful the development of technology is, technology can be operated only through the support of electricity. Actually, the development of information technology not only influences the local status of employment, social processes, and construction of economy; but also plays a influential role in the processes of global information economy. As Carnoy, Castell et al. state,

The global information economy is 'based less on the location of natural resources, cheap and abundant labour, or even capital stock, and more and more on the capacity to create new knowledge and apply it rapidly, via information processing and telecommunications, to a wide range of human activities in ever-broadening space and time' (Robins 1997: 24).

Angell's view is that under the conditions of global information economy, the existence of the work place will not be necessary, as the networked places will take over the status of the work place (Robins 1997: 27). If Angell's idea is correct, the numbers of employees will decrease naturally. For example, on-line business is becoming more and more popular in the age of telecommunications and computer networks. Transactions will be processed through a virtual market. Traditionally, a successful transaction requires a place, where commodities are displayed; certain people to work there, such as sales; and a warehouse, to store the goods in stock. Today, this situation may not be necessary any more as consumers are able to glance at products through the Internet. In other words, the jobs decline will happen since there is no place or office, and so the positions of sales will disappear. Mitchell provides the process of how on-line business works, and its strategy:

'The necessary connection between buyers and sellers is established not through physical proximity but through logical linkage. It is all done with software and databases. Merchants get to potential customers by accessing lists of electronic addresses; the key to successful marketing is not being in the right neighbourhood with the right sorts of customers for whom to lay out wares, but ... having the right lists for sending out advertising' (Robins 1997: 25).

The success of telecommunications and computer networks also affects other occupations such as bank jobs. According to Ian [?], 'It is estimated that 150,000 UK bank jobs will eventually be lost because of automation. Millions of jobs will be lost if teleshopping takes off' (Robins 1997: 53). On the other hand, Giddens criticises the impact of industrialism, saying it is 'plainly not limited to the sphere of production, but affects many aspects of day-to-day life, as well as influencing the generic character of human interaction with material environment' (1990: 76).

\section{Conclusion}

Under the development of information technology, employees seem have to undergone more negative effects than positive effects. There is no denying that technology creates more opportunities to employees. However, the term 'opportunities' here may refer to a higher education background, or more skills and professional knowledge. In the position of those employees who have no specific knowledge or valuable skills, they will belong to the unemployment category sooner or later.

In the positive effects on employee, Wilson stresses that 'where jobs are properly designed, information technology can greatly improve satisfaction with the job, afford greater variety and interest, and increase self-confidence' (Taylor et al. 1985: 63). From Briggs' point of view, 'the wide availability of high quality information will lead to the devolution of 
decision making. Managers will be handling more information relating to more areas of interest' (Taylor et al. 1985: 63). This idea is only applied to the position of managers. In the long run, the numbers of managers only rank as few in a company. In other words, larger portions of employees are only workers.

As previous sections have mentioned about the importance of knowledge, it will become the only one way to achieve a better life and to survive in an information society. Even though the construction of a society will be changed or reformed after few decades, or over a century, the crucial status of knowledge can be considered as a life buoy.

\section{References}

Bennett, T. et al. (2005). New Keywords. Oxford: Blackwell Publishing.

Castells, M. (1996). The Rise of the Network Society. Oxford: Blackwell.

Freeman, C. and Soete, L. (1994). Work for all or Mass Unemployment. London: Pinter.

Giddens, A. (1990). The Consequences of Modernity. Cambridge: Polity Press.

Phitchinis, S.G. (1983). Computer Technology and Employment. London: MacMillan Press.

Robins, K. (1997). What in the World's Going on? In: Du Gay, eds. Production of Culture/Cultures of Production. London: Sage.

Shaiken, H. (1994). Work Transformed. New York: Holt, Rinehart and Winston.

Tapscott, D. (1996). The Digital Economy: Promise and Peril in the Age of Networked Intelligence. New York: McGraw-Hill.

Taylor, A., Coppin, P., Wealthy, P. (1985). The Impact of New Technology on Local Employment. Hampshire: Gower. 